\title{
The Kaali Impact as Trigger of a Mega-Tsunami Event and Violent Seismotectonics in Sweden
}

\author{
Nils-Axel Mörner \\ Paleogeophysics \& Geodynamics, Stockholm, Sweden \\ Email: morner@pog.nu
}

How to cite this paper: Mörner, N.-A. (2020) The Kaali Impact as Trigger of a Mega-Tsunami Event and Violent Seismotectonics in Sweden. International Journal of Astronomy and Astrophysics, 10, 235-246. https://doi.org/10.4236/ijaa.2020.103013

Received: August 19, 2020

Accepted: September 21, 2020

Published: September 24, 2020

Copyright (c) 2020 by author(s) and Scientific Research Publishing Inc. This work is licensed under the Creative Commons Attribution International License (CC BY 4.0).

http://creativecommons.org/licenses/by/4.0/

\begin{abstract}
A meteorite impacted the ground in Estonia forming the Kaali Crater dated at 1183 - 1162 BC. It set up a Baltic-wide mega-tsunami dated at 1171 absolute varve years BC. It also triggered violent seismotectonic effect in Sweden. Ancient legends testify of direct observations of the sky phenomena and personal experiences of the ground shaking and tsunami flooding, which makes the Kaali Crater the oldest impact event documented by humans. The Ragnarök apocalypse is likely to lead its origin from the violent geodynamic activity along the Swedish east coast.
\end{abstract}

\section{Keywords}

Meteor Impact in the Bronze Age, The Kaali Crater, Ground Shaking, Methane Venting Tectonics, Baltic Mega-Tsunami, Ancient Legends, Ragnarök

\section{Introduction}

At about 1200 cal. yrs BC something quite unique occurred in the Baltic region: a meteorite impacted the ground on Saaremaa Island in Estonia giving rise to the Kaali Crater and 8 minor impact marks. At the same time along the Swedish east coast, we record high-magnitude paleoseismic activity, ground shaking with power of fracturing the bedrock, intensive methane venting tectonics, and the occurrence of a mega-tsunami with a run-up on the order of $15 \mathrm{~m}$. In this paper, we propose that all the events occurred at the same time, and that the geodynamic events along the Swedish east coast were all triggered by the Kaali impact.

Supplementary Material to this paper has been posted on ResearchGate [1]. It consists of 3 papers; Observational facts on seismotectonics and a mega-tsunami in Sweden (Mörner; p. 2-18), Radiocarbon chronology of the Kaali Impact (Duffy; p. 19-21) and Searching for a larger meteor fragment falling into the Bal- 
tic Sea (Mörner \& Duffy; pp. 22-23).

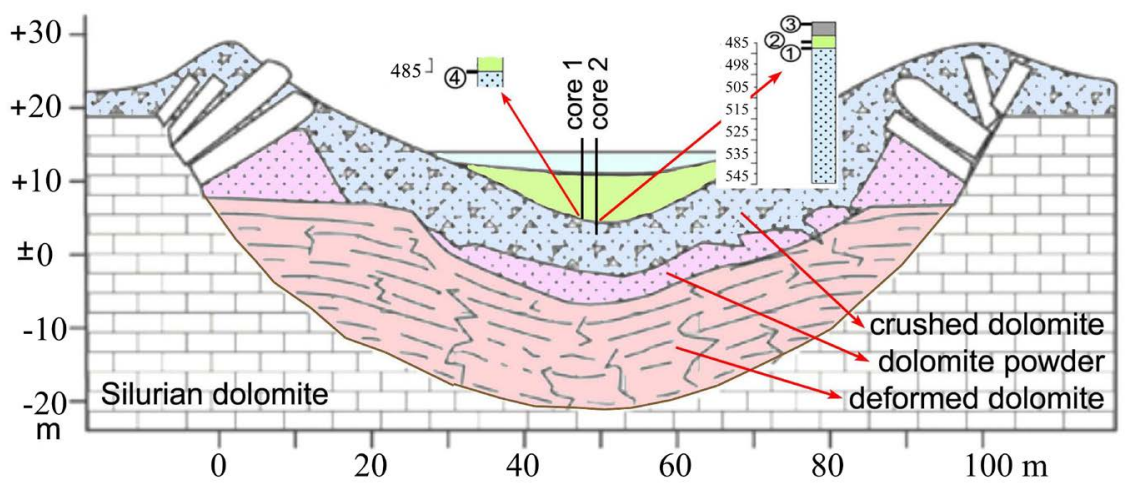

Figure 1. The Kaali Crater [6]. The crater has a visible surface dimension of $60 \mathrm{~m}$ in diameter and $16 \mathrm{~m}$ in depth, but a hidden deformational dimension (pink) of about $110 \mathrm{~m}$ in diameter and $44 \mathrm{~m}$ in depth. The Cores 1 and 2 stratigraphy and position of radiocarbon dates $(1-4)$ are added.

\section{The Kaali Impact Crater}

The Kaali Crater is located on the Silurian dolomite bedrock surface of Saaremaa Island in Estonia. The impact consists of a main crater and 8 minor impact marks. The main crater has a diameter of $60 \mathrm{~m}$ and a depth of $16 \mathrm{~m}$, although the bedrock is deformed down to about $44 \mathrm{~m}$ (Figure 1). The age of the Kaali crater has been debated and given either at around $7500 \mathrm{BP}$ [2] [3] [4] or at 3500 - 2500 BP [5] [6] [7].

The size of the impacting meteorite was estimated at around 450 tons hitting the ground with a velocity of about $15 \mathrm{~km} \cdot \mathrm{s}^{-1}$ and an energy release of about $4 \times 10^{12} \mathrm{~J}$, corresponding to an explosion of $4-20$ kilotons of trotyl [7]. The trajectory has also been interpreted quite differently, viz. from the ENE [6] or from the SSE [3]. Nevertheless, the impact must have set up quite a severe shock-wave in the bedrock.

The light phenomenon in the sky, the sound at impact and the ground shaking must have struck the people with both fear and fascination. In fact, the Kaali impact coincides closely with an exceptional peak (Figure 2) in geodynamic activity recorded at 13 sites along the Swedish east coast [8] [9] [10]. Ancient local legends vividly record both sky phenomena and violent ground shaking, which suggest that the Kaali Crater may be the oldest impact event recorded by humans [11], and potentially the best meteorite impact hazard event anywhere.

\section{Late Holocene Seismotectonics in Sweden}

In today's instrumental recording of seismic activity, Sweden is a region of generally low seismic activity. In deglacial and early Holocene time, however, Sweden was a high-seismic region [8] [12] [13]. The Swedish Paleoseismological Catalogue includes 66 documented, dated and published events [14] [15]. Their distribution in time is given in Figure 2. The estimated magnitude and distribution include 8 M5 - 6, 35 M6 - 7, 12 M7 - 8 and $7 \mathrm{M}>8$ events [8] [14].

There is a clear relationship between the rate of glacial isostatic uplift and the 


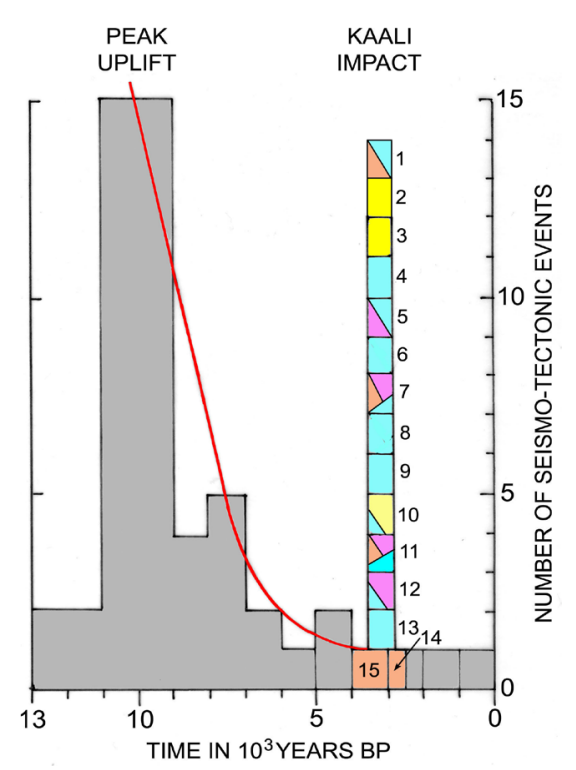

Figure 2. Histogram of 63 paleoseismic events in the last 13,000 years. With a peak of about $50 \%$ at the peak rate of uplift, it decreases with time (red line) except for a very strong peak at around $3000 \mathrm{BP}$ (coloured events: yellow = bedrock deformation, orange = earthquake, violet $=$ MVT, blue $=$ tsunami) here interpreted as effects of the Kaali Impact.

number of paleoseismic events [8] [12]. Figure 2 gives a histogram of the number of events per millennia for the last 13,000 years. There is a peak of paleoseismic events coinciding with the peak of glacial isostatic uplift at about 10,000 BP, after which there seems to be a generally decreasing trend with time (red line in Figure 2), except for a very surprising and abnormal second peak of 13 events at around $3000 \mathrm{BP}$. This peak calls for an explanation in other terms than normal seismotectonics of the area (grey field in Figure 2). In fact, it calls for a point event.

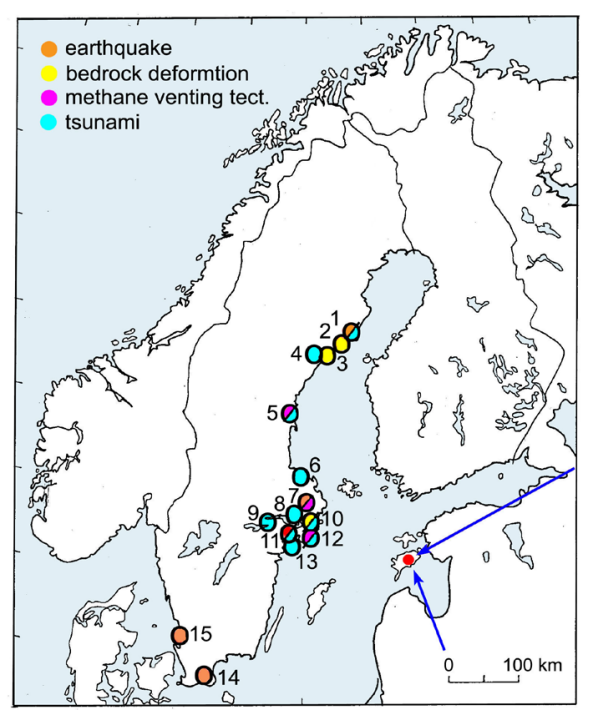

Figure 3. Location of the 15 sites in Sweden recording seismotectonic effects at around 3000 BP (signs marked 1 - 15 with same colour code as in Figure 2) and the Kaali impact crater with proposed trajectories from the ENE [6] or the SSE [3]. The working hypothesis is that the Kaali impact triggered the seismotectonic effects recorded in Sites $1-13$. 
The second peak at about $3000 \mathrm{BP}$ refers to 13 sites consisting of four types of seismotectonic data (Figure 2 and Figure 3), viz. earthquakes (orange), bedrock deformations from ground shaking (yellow), methane venting tectonics (purple) and tsunami records (blue).

The 13 sites (plus Sites 14 and 15, which seem to belong to the zone of "normal" paleosismic activity in Sweden; marked grey in Figure 2) are all described in detail in the Supplementary Material ([1], Figures 1-23).

Earthquake records are documented in Sites 1 ([1] Figure 1), 7 ([1] Figure 7-8) and 11 ([1] Figure 16). At Rödbäck gravel pit (just south of Umeå) there is a quite remarkable record of large-scale liquefaction including venting structures, slides and faults (Figure 4) from a paleoseismic event occurring at about 3000 $\mathrm{BP}$, and having a magnitude of about M7, or rather M7.8 [1] [8] [15] [16].

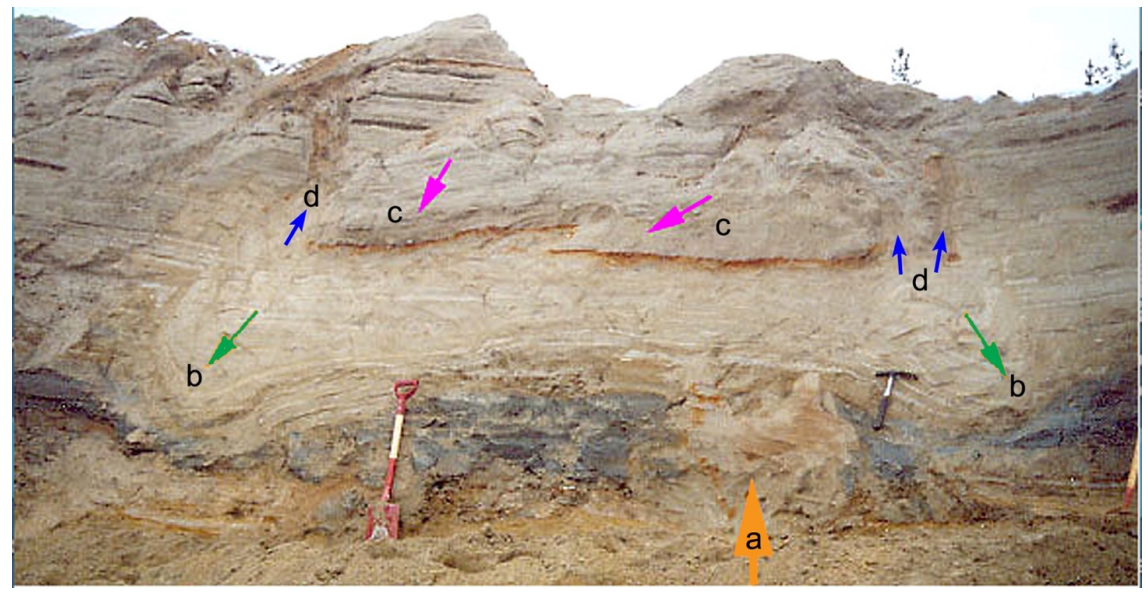

Figure 4. The Röbäck gravel pit in 2002 [8] recording large-scale liquefaction structures in the sediments from about $4000 \mathrm{BP}$. The Baltic clays have been penetrated by vented sand (a), liquefied sandy-gravelly beds have sunk down (b), sediment blocks have become down-faulted (c), and at the sides liquefied sand has vented to the surface (d). In a nearby site, an archaeological site dated at $3585 \pm 115$ cal. yrs BP is covered littoral sand of an $11 \mathrm{~m}$ tsunami event [1] [10].

Sites 14 and 15 in southern Sweden also refer to typical paleoseismic records. Those sites were regarded as "normal" paleoseismic events (belonging to the grey field in Figure 2), and were left out of the analysis of the 3000 BP peak in geodynamic events here discussed.

Heavy ground shaking with capacity of bedrock deformation was observed in Sites 2 and 3 [17], in Site 7 ([1] Figures 7-8), in Site 10 ([1] Figures 14-15), and in Site 11. Whether the ground shaking was due to earthquake or MVT is still an open question.

Some of the events (Sites 5, 7, 11, and 12) refer to explosive methane venting tectonics [8] [9] [10] [18]. These events were interpreted as being generated by rapid phase-transitions of methane hydrate (accumulated in voids and fractures in the bedrock) into methane gas. This gave rise to explosive methane venting tectonics or MVT events. The Sites 5 and 12 MVT events are estimated to correspond to $\mathrm{M} 8.0$ ground shaking events [16]. 
In 11 of the sites, high-amplitude tsunamis were recorded (see detailed review in [10] and older descriptions in [8] [9] [16] [19] [20]. They are recorded [10] in Sites $1(11 \mathrm{~m}), 4(14 \mathrm{~m}), 5(12 \mathrm{~m}), 6$ (>6 m, maybe even $21.5 \mathrm{~m}), 7(20.5 \mathrm{~m}), 8$ (13.5 - $16.5 \mathrm{~m}), 9(14.5 \mathrm{~m}), 10(9 \mathrm{~m}), 11(14.5-21 \mathrm{~m}), 12(10 \mathrm{~m})$ and $13(16 \mathrm{~m})$. This implies that we, in fact, are dealing with one Baltic-wide tsunami event [10], despite previous local site interpretations (the absence of data in SE Sweden is simply a lack of investigations). Furthermore, the tsunami event coincide in time with the Kaali impact (below: Figure 5).

At Site 5, 6 and, 8 the tsunami wave was recorded both in its submarine phase and in its run-up phase over land ([1] Figures 5, 11, 12), which is quite unique, but provide extra strength to a proper understanding of the tsunami wave propagation process.

The tsunami data base includes some 60 radiocarbon dates. Omitting dates that refer to redeposited older material, the other dates range themselves into three groups [10]:

1) 1650 - $1300 \mathrm{cal}$. yrs BC: 13 dates referring to the period before the event.

2) $1300-1060 \mathrm{cal}$. yrs BC: 11 dates referring to the time at about the event (i.e. $1180 \pm 120 \mathrm{BC})$.

3) 1060 - $750 \mathrm{cal}$. yrs BC: 23 dates referring to the period after the event.

This implies that the tsunami event occurred within a zone of $1180 \pm 120 \mathrm{cal}$. yrs BC. At Site 4, there is a $14 \mathrm{~m}$ tsunami recorded ([1] Figure 2, and [10]), which can be tied to the postglacial varved clay chronology of the River Ångermanälven sediments [21] [22] [23]. This provides an absolute age of 1171 varves BC (Figure 5).

The mega-tsunami recorded in 11 sites in Sweden (Figure 2 and Figure 3) is, of course, contemporaneous, representing one mega-tsunami of Baltic-wide dimension. The absolute varve date in Site 4 gives an age of 1171 varve years BC (with a margin of error of about $+10 /-30$ varves according to [23]).

It is hereby proposed that the 3000 BP peak of seismotectonic events in Sweden and the Baltic-wide mega-tsunami event were all triggered by the Kaali Impact. The geographical distribution of events in Sweden is given in Figure 3.

\section{Ancient Legends}

The traumatic experiences of violent natural phenomena shaking the Earth and being observed in the sky are recorded in the Icelandic Edda [24] [25] and in the Finnish Kalevala Epos [26] [27]. Below follow a few quotations highlighting the vivid messages from the ancient oral tradition.

In Váluspá of the Edda, it is stated that: The sun blackens, the earth sinks into sea // Bright stars fall from heaven // Flames lash against life's support (Yggdrasi) // High gorges the heat against heaven itself. In Hyndla of the Edda, the sea flooding is spelled out: The sea storms against the heaven // Floods over the land. In Gylfaginning of the Edda, the earthquake shaking is well presented: The whole earth and the mountains quake // The trees are un-rooted and the mountains collapse // All bounds are broken and torn apart. 
The Kalevala Epos is strongly focused on the extraordinary sky-phenomena. In Song 47, we get the picture of what had happened: The high skies opened, the whole sky broke // Fire rushes through the sky, it shoots like a star shot // Lightens all across the skies, rushes through the clouds, and the wise old Väinämöinen spoke: Noble brother Ilmarinen // Let us go to find out, let us go and see // What sort of fire that occurred, what sort of spark that was seen // Gliding fast from the high skies, all the way down into the ground.

\section{Ragnarök}

With the new geological data here presented, there now seems to be logical reasons for seeking the origin of the Nordic tales of Ragnarök, the Fenris Wolf, the Midgard Serpent and the Surt giant in people's own experiences in the Bronze Age at about $1200 \mathrm{BC}$

The Nordic mythology (the Asa Creed) includes the stories about the Ragnarök apocalypse, the Midgard Serpent, and the Fenris Wolf, which usually are ascribed to the Viking period of the Late Iron Age [24] [25] or to the $6^{\text {th }}$ century AD volcanic and climatic events [28] [29] (24-25). The origin of the mythology may go much further back in time, however [18] [30] [31] [32] [33].

The tale of the Fenris Wolf [31] recounts the story of a giant wolf threatening to destroy the Earth and therefore was chained deep in the mountains, but when he howled the ground and mountains trembled violently and deep fractures formed and rock fragments were thrown around. This sounds like a perfect description of earthquakes. Therefore, the tale of the Fenris Wolf [31] seems to get a logical explanation in the high seismic activity in Sweden in the Late Holocene [8] [10] [32], particularly the remarkable concentration of paleoseismic events at about $3000 \mathrm{BP}$ [31] [32] [33]. Besides, several place names refer to sounds or fractured bedrock [31] [33].

Just as the tales of Ragnarök (the apocalypse) and the Fenris Wolf (the ground shaking and bedrock fracturing) hark back to ancestral traumatic experiences of the violent natural phenomena taking place at about 3000 BP so might the legend of the Midgard Serpent. Tsunami waves rising into a high wall when breaking in over the coasts may be regarded as a giant serpent. Therefore, it seems most significant that the image of a giant sea serpent occurs on a rock carving from the Bronze Age on the Island of Bornholm ([1] Figure 24, [34] Figure 4).

\section{Discussion}

The time coincidence, geodynamic coupling, tsunami dimension and legend background need some additional discussion.

The exact age of the Kaali Crater has been a matter of debate [2] [3] [5] [6] [7] [35]. The span of uncertainty is from about 1000 to 1700 cal. yrs BC (or about 2850 to $3300 \mathrm{BP}$ ). Secondly, the mode of sedimentary infill of the crater basin needs reconsideration. According to Veski et al. [6], the crater was "an empty hole" after the impact, into which "loose material was gradually washed to the bottom of the cra- 
ter". The Baltic-wide tsunami documented in Sweden, is likely also to have invaded the crater and deposited a mixed material at its base, which seems to fit well with the description by Veski et al. [6] of the basal sediments: a "dolomite diamicton (unsorted sediment that contains a wide range of particle sizes from clay to gravel)" and calcareous gyttja with eroded diatoms. At the base of core 1, there is a peat [35] dated at $3390 \pm 35 \mathrm{BP}$ or $1680 \pm 60 \mathrm{cal}$. yrs BP. It seems quite strange to have "peat" at the base of the crater-lake. Rather does it indicate the inflow from re-deposited peaty material of pre-impact age. If so, the age of the impact post-dates the age of the peat. Only 3 dates come from the base of core 2 (Figure 1); sample 1 (1600 \pm 90 cal. yrs BC) comes from the top of the carbonate rich diamicton, sample $2(1025 \pm$ $105 \mathrm{cal}$. yrs BC) was taken $3 \mathrm{~cm}$ up in the lake gyttja, sample 3 (915 $\pm 85 \mathrm{cal}$. yrs BC) is from the detrital gyttja and must be too young.

In order to provide a better dating analysis, Duffy kindly constructed an OxCal Poissonian depositional sequence model (P_sequence). This model ([1] Figure 24) yields a boundary age for the onset of deposition in the crater of 1183 1162 BC (95\%).

This value is in perfect agreement with the absolute varve date of $1171 \mathrm{BC}$, obtained of the tsunami event in Site 4. It also agrees well with the zone of dates referring to "at about" the event ranging from 1300 to 1060 cal. yrs BC or $1180 \pm$ 120 cal. yrs BC (above).

Figure 5 illustrates the excellent agreement between the date of the Kaali Crater and the tsunami dates in Sweden, where the absolute varve date of $1171 \mathrm{BC}$ stands out as exceptional. By this, the time coincidence between the impact and the geodynamic effects in Sweden seems settled.

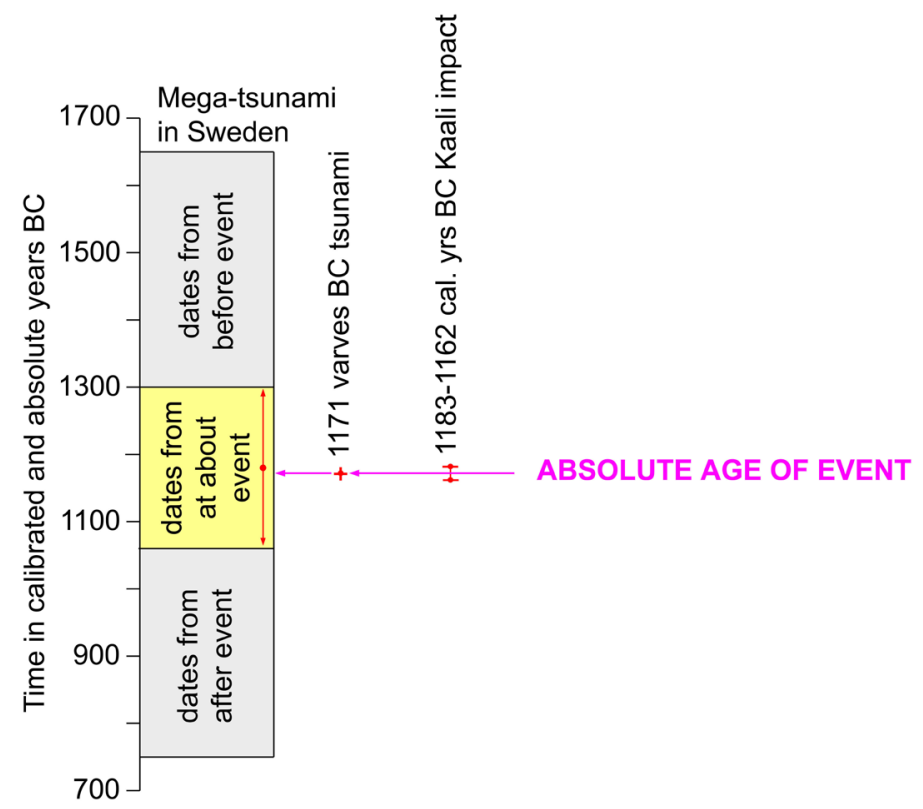

Figure 5. Chronology of the events discussed. The Kali impact is dated at $1183-1162$ cal. yrs BC, and the mega-tsunami event in Sweden is assigned an absolute varve age of 1171 varves BC in Site 4 (in good agreement with the radiocarbon chronology of the tsunami event; left column). 
The geodynamic coupling between impact forces and seismotectonic effects in Sweden (a distance of up to $400 \mathrm{~km}$ to Site 1 and $160 \mathrm{~km}$ to Site 11) is another prime issue.

Earthquakes and ground shaking have been recorded at far distances from historical impact events. The Tunguska event in 1908 generated an M 4.7 earthquake [36] with a seismic wave over $5300 \mathrm{~km}$ [37]. At the Chelyabinsk impact event in 2013, the seismic ground shaking was recorded "at least up to $4000 \mathrm{~km}$ away" [37], and the authors concluded that "distant seismic recording can agree remarkably well with local meteor observations".

Methane venting tectonics (MVT) seem sometimes to have been generated over very long distances [9]; at the Saguenay M 5.9 earthquake in Canada in 1988, violent methane venting was observed $800 \mathrm{~km}$ to the SW, and at the M 7.7 earthquake in Pakistan in 2013, methane venting tectonics occurred $400 \mathrm{~km}$ to the south. In both these cases, it seems to have been the seismic shock waves in the crust that set up the MVT events [9]. A recent MVT event seems to have been recorded in Timor in 2018 [38]: the locals heard a strong explosion, found a former bedrock fractured into pieces and gas venting from the ground (Figure 6). The gas was burning (obviously set on fire by sparks from the colliding bedrock fragments (cf. [18]).

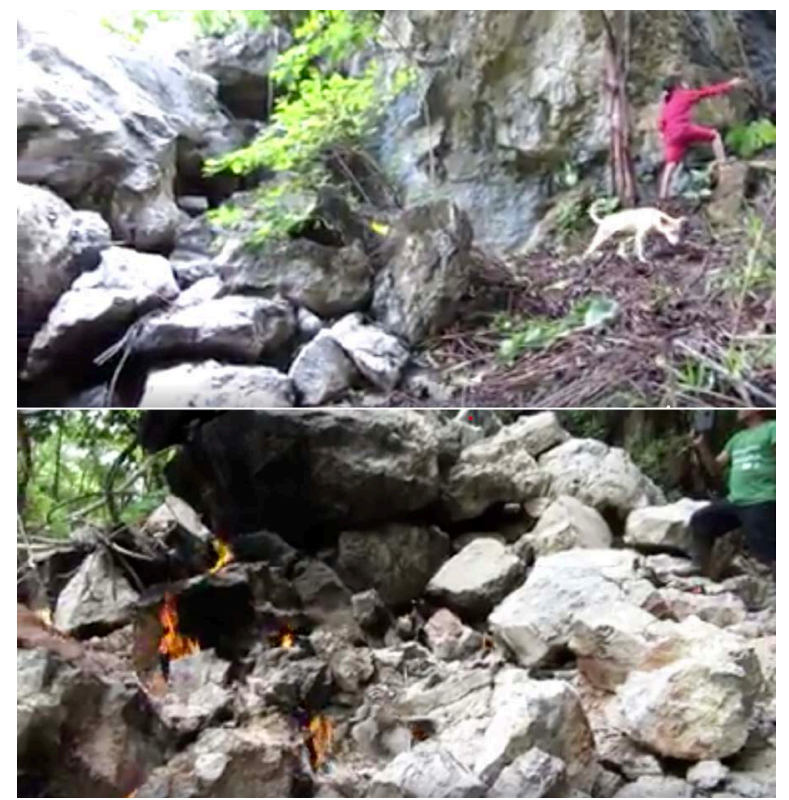

Figure 6. View of the Timor 2018 event with fractured bedrock and burning methane degassing [38], a recent example of methane venting tectonics [9] and burning gas [18].

Actual MVT was only observed in Sites 5, 7, 11, 12. The ground-shaking effect of the MVT-event at Sites 5 and 12 were estimated at M 8.0 [16]. Such a high ground shaking may well explain the deformational effects observed in Sites 1,2, $3,7,10$, and 11 .

The tsunami events are observed in 11 of the 13 sites. The tsunami wave-height 
or run-up height is now established at values ranging from 10 to $16.5 \mathrm{~m}$ (above). This rules out a sequence of local events, in favour of one big Baltic-wide event. Either we may be dealing with an atmospheric shock wave (meteo-tsunami; [37] [39]) induced by the impact, or a normal tsunami generation of an impact hitting the Baltic Sea. The dimension of the Kaali Crater (60 - $100 \mathrm{~m}$ wide and $16 \mathrm{~m}$ deep) and its elevation $(+22 \mathrm{~m})$ shed some doubt that this impact would be strong enough to generate the mega-tsunami and the seismotectonic effects observed in Sweden. Therefore, it seems probable that a hitherto unknown larger meteor fragment fell directly into the Baltic Sea somewhere between Estonia and Sweden ([1] Figures 25-26).

For the history of impact events [11], it seems important that the Kaali impact event may now be considered the oldest event observed and recorded by humans. Previously, the oldest events were the 616 BC and 645 BC events in China [11].

\section{Conclusions}

The ice cover in the European Arctic Seas affects the biologic productivity and the Kaali crater represents an important event. Available radiocarbon dates were reinterpreted according to the OxCal Poissonian depositional sequence model providing an age of 1183 - 1162 cal. yrs BC for the onset of sedimentation in the crater ([1] p. 2). This is co-incidental with the date of the mega-tsunami in Sweden, absolutely dated by varves at 1171 varves BC.

The 13 sites in Sweden bear witness of severe ground shaking, seismotectonics and methane venting tectonics. They all occur at the same time as the mega-tsunami, and can hence be directly coupled to the Kaali impact.

It is concluded that the Kaali impact (Figure 1) triggered the 13 deformational events recorded in Sweden (Figure 2) at 1171 absolute years BC (1183 - 1162 cal. yrs BC for the Kaali crater), and that all this became mixed into ancient legends because it terrified and fascinated the local people. Hence, the Kaali impact event may be considered the oldest event observed and recorded by humans.

\section{Acknowledgements}

I acknowledge inspiring collaboration with Brendan Duffy [1]. The author is indebted to Dr. Pamela Matlack-Klein for linguistically checking the paper. The Supplementary Material file can be downloaded from ResearchGate, or ordered from the author.

\section{Conflicts of Interest}

The author declares no conflicts of interest regarding the publication of this paper.

\section{References}

[1] Mörner, N.-A. and Duffy, B. (2020) Supplementary Material. Posted on ResearchGate, September 17, 2020.

https://www.researchgate.net/publication/344287444 Supplementary Materials Ob 
servation-

al facts on seismotectonics and a mega-tsunami in Sweden Searching for a la rger meteor fragment falling into the Baltic Sea\#fullTextFileContent

[2] Raukas, A., Tiirmaa, R., Kaup, E. and Kimmel K. (2001) The Age of the Ilumetsa Meteorite Craters in Southeast Estonia. Meteoritics \& Planetary Science, 36, 1057-1514. https://doi.org/10.1111/j.1945-5100.2001.tb01842.x

[3] Moora, T., Raukas, A. and Stankowski, W. (2012) Dating of the Reo Site (Island of Saaremaa, Estonia) with Silicate and Iron Microspherules Points to an Exact Age of the Fall of the Kaali Meteorite. Geochronometria, 39, 262-267.

https://doi.org/10.2478/s13386-012-0015-3

[4] Uscinowicz, G. (2014) Impact Craters and the Extraterrestrial Matter in Their Surroundings: Case of Morasko (Poland) and Kaali (Estonia). Baltica, 27, 24-31.

https://doi.org/10.5200/baltica.2014.27.03

[5] Rasmussen, K.L., Aaby, B. and Gwozdz, R. (2000) The Age of the Kaalijärv Meteorite Craters. Meteoritics \& Planetary Science, 35, 1067-1071. https://doi.org/10.1111/j.1945-5100.2000.tb01493.x

[6] Veski, S., Heinsalu, A., Lang, V., Kestlane, U. and Possnert, G. (2004) The Age of the Kaali Meteorite Craters and the Effect of the Impact on the Environment and Man: Evidence from inside the Kaali Craters, Island of Saaremaa, Estonia. Vegetation History and Archaeobotany, 13, 197-206. https://doi.org/10.1007/s00334-004-0043-x

[7] Veski, S., Heinsalu, A., Poska, A ., Saarse, L. and Vassiljev, J. (2018) The Physical and Social Effects of the Kaali Meteorite Impact-A Review. In: Bobrowsky, P.T. and Rickman, H., Eds., Comet/ Asteroid Impacts and Human Society, Springer, Berlin, 265-275. https://doi.org/10.1007/978-3-540-32711-0_15

[8] Mörner, N.-A. (2003) Paleoseismicity of Sweden: A Novel Paradigm. A Contribution to INQUA from Its Sub-Commission on Paleoseismology at 16th International INQUA Congress in Reno, Nevada. Stockholm University, (P \& G Print, 2003), Stockholm, 1-320.

[9] Mörner, N.-A. (2017) Methane Hydrate in Crystalline Bedrock and Explosive Methane Venting Tectonics. Earth-Science Reviews, 169, 202-212.

https://doi.org/10.1016/j.earscirev.2017.05.003

[10] Mörner, N.-A., Ambrosiani, B. and Anderson-Ambrosiani, P. (2020) A Mega-Tsunami in the Baltic Sea 3000 BP: Geological and Archaeological Records from the Bronze Age in the Lake Mälaren Area in Sweden. International Journal of Geosciences.

[11] Velasco Herrera, V.M. and Cordero, G. (2016) The Variability of Meteoroid Falling. Planetary and Space Science, 131, 111-118. https://doi.org/10.1016/j.pss.2016.08.005

[12] Möner, N.-A., Ambrosiani, B. and Anderson-Ambrosiani, P. (2020) A Mega-Tsunami in the Baltic Sea 1171 BC: Geological Records with Special Reference to the Lake Malaren Area in Sweden. International Journal of Geosciences. (In Press)

[13] Mörner, N.-A. (2011) Paleoseismology: The Application of Multiple Parameters in Four Case Studies in Sweden. Quaternary International, 242, 65-75. https://doi.org/10.1016/j.quaint.2011.03.054

[14] Mörner, N.-A. (2013) Pattern in Seismology and Palaeoseismology, and Their Application to Long-Term Hazard Assessments-The Swedish Case in View of Nuclear Waste Management. Pattern Recognition in Physics, 1, 75-89. https://doi.org/10.5194/prp-1-75-2013

[15] Mörner, N.-A. (2016) Seismic Hazard Assessment: A Challenge for Science and 
Geoethics. International Journal of Earthquake Engineering and Hazard Mitigation, 4, 64-70.

[16] Mörner, N.-A. (2017) Converting Tsunami Wave Heights to Earthquake Magnitudes. Open Journal of Earthquake Research, 6, 89-97.

https://doi.org/10.4236/ojer.2017.62005

[17] Sjöberg, R. (2018) Vad hände efter norrlandskusten för tre till fyra tusen år sedan? Grottan, 2018, 39-45.

[18] Mörner, N.-A. and Duffy, C. (2020) The Ancient Legend about Surt and the Novel Concept of Methane Venting Tectonics (MVT). Archaeological Discovery, 8, 288-294. https://doi.org/10.4236/ad.2020.83016

[19] Mörner, N.-A. and Dawson, S. (2011) Traces of Tsunami Events in Off- and On-Shore Environments. Case Studies in the Maldives Scotland and Sweden. In: Mörner, N.-A., Ed., The Tsunami Threat: Research and Technology, IntechOpen, London, 371-388. https://doi.org/10.5772/13686

[20] Mörner, N.-A. (2016) Tsunamis in Sweden: Occurrence and Characteristics. In: Mokhtari, M., Ed., Tsunami, IntechOpen, London, 115-133. https://doi.org/10.5772/63956

[21] Lidén, R. (1938) Den senkvartära strandförskjutningens förlopp och kronologi i Ångermanland. Geologiska Föreningen i Stockholm Förhandlingar, 60, 397-404. https://doi.org/10.1080/11035893809445012

[22] Cato, I. (1987) On the Definite Connection of the Swedish Time Scale with the Present. Geological Survey of Sweden, Series Ca 68, Uppsala, 1-55.

[23] Cato, I. (1998) Ragnar Lidéns postglacial varve chronology from the Ångermanlanälven valley, northern Sweden. Sveriges geologiska undersökning, Uppsala, Series Ca 88, 1-88.

[24] Sturlasson, S. (1220) Den Prosaiska Eddan (Snorre's Edda): Codex Upsaliensis, DG 11. Den Poetiska Eddan. Codex Regius, Det Kongl. Bibl. Köpenhavn (about 1220).

[25] Faulkes, A. (1982) Edda. Oxford Univ. Press, Oxford.

[26] Lönnrot, E. (1835-36) Kalevala, the Finnish National Epos. Written down 1835 and 1836.

[27] Crawford, J.M. (1888) The Kalevala. The Epic Poem of Finland. Project Gutenberg, Vol. 1 and 2.

[28] Gräslund, B. and Price, N. (2012) Twilight the Gods? The "Dust Veil Event" of AD 536 in Critical Perspective. Antiquity, 86, 428-443.

https://doi.org/10.1017/S0003598X00062852

[29] Nordvik, M. and Riede, F. (2018) Are There Echoes of the AD 536 Event in the Viking Ragnarok Myth? A Critical Appraisal. Environment and History, 24, 303-324. https://doi.org/10.3197/096734018X15137949591981

[30] Scott Littleton, C. (1964) The Comparative Indo-European Mythology of George Dumézil. Journal of the Folklore Institute, 1, 147-166. https://doi.org/10.2307/3813900

[31] Mörner, N.-A. (2007) The Fenris Wolf in the Nordic Asa Creed in the Light of Paleoseismics. In: Piccardi, L. and Masse, W.B., Eds., Myth and Geology, Geological Society, London, Spec. Publ. 273, 117-119. https://doi.org/10.1144/GSL.SP.2007.273.01.10

[32] Mörner, N.-A. (2009) Late Holocene Earthquake Geology in Sweden. Geological Society, London, Spec. Publ. 316, 179-188. https://doi.org/10.1144/SP316.11

[33] Mörner, N.-A. and Strandberg, S. (2009) Marviken. Geologiskt baserad namntolkning. 
Saga och Sed, Kungl. Gustav Adolfs Akademiens Årsbok 2009, 179-184.

[34] Mörner, N.-A. (2020) The Kaali Impact, Coincidental Deformations and Tsunamis, and Ancient Legends. 10th International INQUA Meeting on Paleoseismology, Active Tectonics and Archeoseismology (PATA), Hornitos, 8-12 November 2020, Extended Abstracts.

[35] Saarse, L., Rajamäe, R., Heinsalu, A. and Vassiljev, J. (1991) The Biostratigraphy of Sediments Deposited in the Lake Kaali Meteorite Impact Structure, Saaremaa Island, Estonia. Bulletin of the Geological Society of Finland 63, 129-139. https://doi.org/10.17741/bgsf/63.2.006

[36] Ben-Menahem, A. (1975) Source Parameters of the Siberian Explosion of June 30, 1908, from Analysis and Synthesis of Seismic Signals at Four Stations. Physics of the Earth and Planetary Interiors, 11, 1-35.

https://doi.org/10.1016/0031-9201(75)90072-2

[37] Heimann, S., Gonzalez, A., Wang, R., Cesca, S. and Dahm, T. (2013) Seismic Characterization of the Chelyabinsk Meteor's Terminal Explosion. Seismological Research Letters, 84, 1021-1025. https://doi.org/10.1785/0220130042

[38] Herculano, N. (2018) Video of Explosive Methane Venting Tectonic Event in Timor Island. https://www.facebook.com/nelson.herculano.16/videos/10212446793031470

[39] Mörner, N.-A. (2019) Tsunami Deposits. In: Finkl, C.W. and Makowski, C., Eds., Encyclopedia of Coastal Science, Springer, Berlin, Vol. 2, 1805-1808. 